\title{
Arbeidsrelatert kols
}

BAKGRUNN Arbeidsrelatert kols oppstår ved eksponering for skadelige partikler og gasser i arbeid, også hos ikke-røykere. Formålet med denne artikkelen er å presentere nyere funn om sammenhengen mellom eksponering i arbeid og kols. Vi gjennomgår i tillegg diagnostiske og prognostiske overveininger og muligheter for forebygging.

KUNNSKAPSGRUNNLAG Vi har gjort litteratursøk i Medline og Embase for perioden fra mai 2009 til juli 2014. Studier uten lungefunksjonsmålinger og studier som ikke omhandlet arbeidsrelatert eksponering ble ekskludert. I tillegg har vi supplert med tre prospektive studier om lungefunksjon og eksponering $\mathrm{i}$ arbeid som ikke var indeksert med de benyttede søketermer for obstruktiv lungesykdom.

RESULTATER Tre populasjonsstudier og åtte studier som omhandlet en bransje eller industri ble inkludert. I nyere studier finner man assosiasjon mellom eksponering og økt risiko for kols i bygg- og anleggsbransjen, i smelteverksindustrien, ved sementproduksjon og i tekstilindustrien. For øvrig bekreftes funn fra tidligere oversiktsstudier.

FORTOLKNING Eksponering for en rekke organiske og uorganiske partikler og gasser i arbeid kan gi kols også ved dagens eksponeringsnivåer. Leger bør spørre om slik eksponering ved både mistenkt og etablert kols og ha lav terskel for henvisning til arbeidsmedisinsk vurdering.

Kronisk obstruktiv lungesykdom (kols) er definert som sykdom karakterisert av obstruksjon i luftveiene som ikke er fullt reversibel, som er progredierende og assosiert med patologisk inflammatorisk respons ved eksponering for skadelige partikler og gasser (1). Arbeidsrelatert kols er forårsaket eller forverret av eksponering for partikler og gasser på arbeidsplassen (2).

De viktigste kjente risikofaktorene for kols er tobakksrøyking, eksponering i arbeid, luftforurensning, avgasser fra forbrenning av biomasse, residiverende luftveisinfeksjoner, lav sosioøkonomisk status og kronisk obstruksjon som følge av astma (3). I Norge er det nylig vist at i flere landsdeler er forekomsten av kols høyere enn utbredelsen av røyking i de samme områdene skulle tilsi (4).

Studier fra andre land viser at om lag $25 \%$ av pasientene med kols er aldrirøykere (3, 5). Mens eksponering for avgasser ved forbrenning av biomasse er den viktigste ikke-tobakksrelaterte årsaken til kols globalt (3), antas eksponering i arbeid å være blant de viktigste i Norge. Det er kjent at 15-20\% av alle kolstilfeller i Europa og USA er arbeidsrelatert $(2,6,7)$ og at det er en additiv effekt av røyking og eksponering i arbeid (7, 8). Beregninger viser at det vil oppstå 3000 nye tilfeller og dø om lag 200 personer som følge av arbeidsrelatert kols i Norge hvert år (9).

Hvilke eksponeringer i arbeid kan gi kols? I en nyere oversiktsstudie, hvor en av denne artikkelens forfattere (TOBAA) har bidratt, vurderte man studier utgitt $i$ perioden 2003-09 (10). Forfatterne inkluderte 25 populasjonsstudier og 34 bransje- eller industriorienterte studier og konkluderte med at det er vist tilstrekkelig sammenheng mellom en rekke eksponeringer $\mathrm{i}$ arbeid og kols. Yrker og bransjer som var assosiert med økt risiko i denne studien er vist $i$ tabell $1(10,11)$.

Etter 2009 er det publisert flere studier om arbeidsrelatert kols. Formålet med denne artikkelen er å presentere nyere funn. Vi gjennomgår i tillegg diagnostiske og prognostiske overveininger og muligheter for bedre forebygging av arbeidsrelatert kols.

\section{Kunnskapsgrunnlag}

Vi har gjort søk i Medline og Embase (mai 2009-juli 2014) basert på søk fra en tidligere oversiktsstudie (10), begrenset til humane studier på dansk, engelsk, norsk, tysk eller svensk med søkeordene (MeSH-termer): pulmonary disease, chronic obstructive; (chronic obstructive pulmonary disease, OR chronic airflow obstruction copd OR coad OR chronic obstructive lung disease); chronic bronchitis. Kombinasjonen: 1 OR 2 OR 3 ble knyttet sammen (AND) med occupational diseases OR agricutural workers' diseases OR pneumoconiosis, OR Bagasosis, OR miner lung coal OR anthracosis, OR asbestosis OR berylliosis OR byssinosis OR siderosis OR silicosis OR occupational exposure OR work related OR workplace OR work location. I tillegg er enkelttermer trunkert og inkludert som tekstord. Forfatterne har i tillegg tilført tre relevante artikler som ble vurdert på lik linje med de øvrige.

Vi identifiserte tre populasjonsstudier og fem prospektive bransje- eller industriorienterte studier (originalartikler) publisert $\mathrm{i}$

\author{
Anne Kristin Møller Fell \\ anne-kristin.fell@sthf.no \\ Arbeidsmedisinsk avdeling \\ Sykehuset Telemark Skien \\ Tor Olav Brøvig Aasen \\ Yrkesmedisinsk avdeling \\ Haukeland universitetssykehus

\section{Johny Kongerud} \\ Lungemedisinsk avdeling \\ Oslo universitetssykehus, Rikshospitalet \\ og \\ Det medisinske fakultet \\ Universitetet i Oslo \\ uiz \\ Se også kunnskapsprøve \\ på www.tidsskriftet.no/quiz \\ 믈 \\ Engelsk oversettelse på www.tidsskriftet.no \\ > Se lederartikkel i Tidsskriftet nr. 20/2014 \\ side 1916
}

Publisert først på nett

\section{HOVEDBUDSKAP}

Nyere studier viser at det er en sammenheng mellom eksponering i arbeid og økt risiko for kols i bygg- og anleggsbransjen, smelteverksindustrien, ved sementproduksjon og i tekstilindustrien

Det bør være en lav terskel for å spørre om eksponering $\mathrm{i}$ arbeid ved mistenkt og etablert kols og for henvisning til arbeidsmedisinsk utredning

Mistanke om arbeidsrelatert kols skal meldes til Arbeidstilsynet. 
tidsrommet fra mai 2009 til juli 2014. I tillegg har vi supplert med tre prospektive studier om lungefunksjon og eksponering $\mathrm{i}$ arbeid som ikke var indeksert med de benyttede MeSH-søketermer for obstruktiv lungesykdom. Disse diskuteres avslutningsvis. Av plasshensyn og fordi sammenhengen mellom eksponering og funn er mer usikker i tverrsnittsstudier, er disse ikke inkludert. Studier uten lungefunksjonsmåling og studier som ikke omhandlet arbeidsrelatert eksponering er ekskludert.

Figur 1 viser inklusjon og eksklusjon av artikler og tabell $2(12-22)$ oppsummerer inkluderte studier.

\section{Populasjonsstudier}

Resultatene fra en prospektiv studie fra Sveits viser at personer med høygradig eksponering $\mathrm{i}$ arbeid hadde to til fem ganger så høy risiko for kols (GOLD-grad II+) som ueksponerte (12). Man fulgte 4267 personer i ti år og brukte jobbeksponeringsmatriser for å kategorisere eksponering, noe som reduserer feil basert på at syke kan overrapportere eksponering (23). Andelen arbeidsrelatert kols var $23 \%$ hos røykerne og $32-51 \%$ hos ikke-røykerne, avhengig av hvilke kriterier for kols som ble benyttet. Studien bekrefter tidligere funn (3).

I en studie fra USA der man fulgte 8967 personer i tre år ble det observert økt risiko for nyoppstått kronisk hoste og oppspytt for mekanikere, reparatører, renholdere og arbeidstakere som drev med vedlikehold av bygninger sammenliknet med kontrollgruppen (administrasjonen) (13). Det ble ikke observert økt risiko for kols, noe som kan skyldes kort oppfølgingstid og eksklusjon av personer med luftveissymptomer i utgangspunktet. Funnene kan imidlertid indikere økt risiko for kols hvis eksponeringen blir langvarig.

Eksponering $\mathrm{i}$ arbeid generelt og for plantevernmidler spesielt var forbundet med økt risiko for kols i en stor nederlandsk studie $(\mathrm{N}=11$ 851) (14). Forfatterne gjentok studien ved å trekke et nytt utvalg $(n=2364)$ og kunne bekrefte resultatene i denne gruppen. Imidlertid gjenstår det å vise en sammenheng med eksponering for plantevernmidler i flere studier.

Et generelt problem med populasjonsstudier er mangelfulle eksponeringsopplysninger og differensialdiagnostiske vurderinger. I studiene fra Sveits og USA brukes yrkeskoder i stedet for grovere kategorier for eksponering, det gir mer informasjon om hvilke eksponeringer som gir økt risiko.

\section{Bransje- eller industriorienterte studier}

En fordel med studier der man ser på bransje eller industri, er at eksponeringen ofte er
Tabell 1 Eksponering assosiert med økt risiko for utvikling av kols

Industri/arbeidsoppgave Eksponering

\section{Blandet eksponering}

Asfaltarbeid

Bitumen, polysykliske aromatiske hydrokarboner

Glass- og keramikkproduksjon Partikler og gass fra ovner, dekorering og farger

Gruve, bygg-og anlegg Silika, blanding av partikler og gass

Transport

Dieseleksos

Papirproduksjon

Trestøv, toppeksponering ozon, $\mathrm{ClO}_{2}, \mathrm{SO}_{2}$

Petroleumsproduksjon og raffinering Partikler og gass fra produksjon, rengjøring

Tunnelarbeid Silika, oljedamp, blanding av gass og partikler

Metaller

Kadmiumbearbeiding

Kadmium

Sveising

Sveiserøyk

Vanadiumutvinning og bearbeiding

Vanadium

Kjemikalier

Bleking, desinfeksjon

Klor, ammoniakk

Renhold, diverse produksjonsprosesser

Ammoniakk, amoniakkforbindelser

Isocyanatproduksjon, sprøytemaling

Diisocyanater

Ugressbekjempelse

Pesticider

Mineraler

Koksovnsarbeidere

Koks

Kullgruver

Kull, silika

Kvartsutvinning, ovnsarbeidere

Silika

Isolasjonsarbeid

«Man made mineral fibers» (MMMF)

\section{Organiske partikler og gasser}

Bomullsproduksjon

Partikler fra spinning av bomull

Jordbruk

Dyrehold, håndtering av dyr, endotoksin

Dyrefôrproduksjon

Partikler og gass fra produksjon, endotoksin

Kornmøller, bakerier

Kornstøv

Gummiproduksjon

Produksjon av gummi

Jutebearbeiding

Partikler og gass fra produksjon, spinnolje

Trevare- og møbelindustri

Trestøv

1 Basert på funn fra en nordisk systematisk oversiktsstudie (10) og på opplysninger fra studier registrert i Haz-Map, US National Library of Medicine (11), kapitlet om arbeidsrelatert kols 


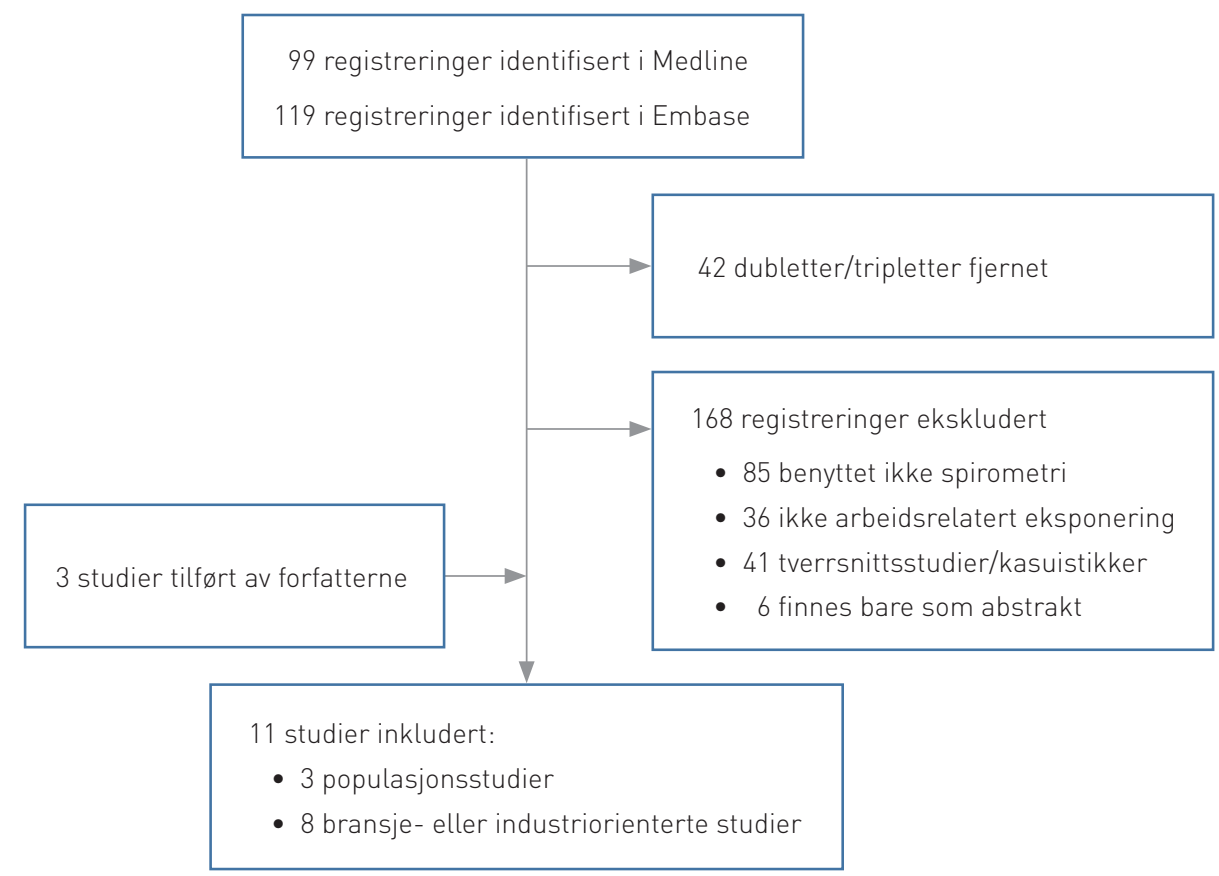

Figur 1 Inkluderte studier om arbeidsrelatert kols for perioden fra mai 2009 til juli 2014

beskrevet og kategorisert. Ulempen er at deltakerne kan være forskjellige fra normalbefolkningen (seleksjon), noe som kan føre til underestimering av risiko.

Eksponering for kvarts forekommer i flere bransjer, som bygg- og anlegg, stålindustri, gruvedrift og ved tunnelarbeid og sandblåsing. En tysk studie med kvartseksponerte gruvearbeidere $(\mathrm{N}=1421)$ bekrefter at eksponering for kvarts $\left(1 \mathrm{mg} / \mathrm{m}^{3}\right.$ over 220 skift à 8 timer per år) kan gi økt risiko for kols grad I (OR 1,8, 95\% KI 1,3-2,6), og man estimerer at eksponering ved $0,1 \mathrm{mg} / \mathrm{m}^{3}$ (norsk grenseverdi) gjennom 40 år vil gi nedsatt lungefunksjon (15). Studien viser at det er økt risiko for kols ved dagens eksponeringsnivåer, hvor ny teknologi for boring i fjell (raskere turtall) kan tenkes å gi flere og finere partikler. Økt forekomst av kols er tidligere vist $\mathrm{i}$ en norsk undersøkelse av tunnelarbeidere fra 2001 (10) og i en stor svensk studie fra 2004 av bygningsarbeidere (24).

Det er et omstridt spørsmål hvorvidt tekstilarbeidere har økt risiko for kols, det har vært sprikende funn i tidligere studier. I en studie fra 2010 fulgte man 447 tekstilarbeidere i 25 år og fant at tidligere eksponering for endotoksin (median 2 086-1289 EU/m ${ }^{3}$ for 1981-92) var assosiert med redusert forsert ekspiratorisk volum etter ett sekund $\left(\mathrm{FEV}_{1}\right)$, mens nylig eksponering (median $98 \mathrm{EU} / \mathrm{m}^{3}$ ) var assosiert med kronisk tungpustethet og hoste (16). Selv om røykedataene ikke var komplette, har forskerne målt eksponering og justert for andre mulige årsaksfaktorer. Det er fortsatt behov for flere studier, men resultatene gir grunnlag for å mistenke økt risiko for kols hos tekstilarbeidere.

Brannmenn er periodevis utsatt for høygradig eksponering, men dette er ikke godt undersøkt. Hos brannmenn som var involvert i rednings og opprydningsarbeid etter terrorhandlingene mot World Trade Center er det funnet økt risiko for kols (17). I en senere studie fant man ikke noen slik sammenheng for brannmenn fra New York som var eksponert i fem år, men ansatt etter 2003 (18). Typisk for 11. september-eksponeringen var at den var svært høygradig, kompleks og besto av pulverisert sement, glass, bly, polysykliske aromatiske hydrokarboner, metaller og polyklorerte bifenyler og hadde $\mathrm{pH}$ på rundt 12 . Selv om det fortsatt er uklart om brannmenn generelt har økt risiko for kols, kan 11. september-studiene være relevante for vurdering av høygradig, sammensatt og alkalisk støveksponering.

Effekter av en annen type alkalisk støv er undersøkt $\mathrm{i}$ en stor prospektiv studie med sementproduksjonsarbeidere fra åtte europeiske land (19). I den norskledede studien fulgte man 4998 arbeidstakere i 4,6 år og fant en dose-respons-sammenheng mellom støvnivå og redusert $\mathrm{FEV}_{1} /{\mathrm{h} ø y d e^{2}}^{2}$ per $\mathrm{mg} /$ $\mathrm{m}^{3}$ og år med 9,7 (95\% KI 7,6-12) for laveste eksponeringskategori $(0,6-1,6 \mathrm{mg} /$ $\left.\mathrm{m}^{3}\right)$ og $19 \quad(15-22) \mathrm{ml}$ for høyeste $\left(5,4-14 \mathrm{mg} / \mathrm{m}^{3}\right)$. Jobbeksponeringsmatriser er benyttet for å kategorisere eksponering, og astmatikere er ekskludert fra analysene. I en studie fra 2014 med 171 sementarbeidere fant man at reduksjon av støvnivåene (fra $10,6 \mathrm{mg} / \mathrm{m}^{3}$ til $5,8 \mathrm{mg} / \mathrm{m}^{3}$ totalt støv) førte til redusert prevalens av kols (fra $22,6 \%$ til $1,9 \%$ ) to år senere (20), dermed antydes en effekt av støvreduserende tiltak. Resultatene gir gode holdepunkter for at det er økt risiko for kols i sementproduksjonsindustrien og vurderes å være relevante også for arbeidstakere i bygg- og anleggsbransjen.

En treårsoppfølging av norske arbeidstakere $(\mathrm{N}=383)$ innen nitratgjødselproduksjon viste fall $\mathrm{i} \mathrm{FEV}_{1}$ på $18 \mathrm{ml} / \mathrm{år}(95 \% \mathrm{KI}$ 10-27) ved eksponering på $1,1 \mathrm{mg} / \mathrm{m}^{3} \mathrm{og}$ $0,2 \mathrm{mg} / \mathrm{m}^{3}$ for henholdsvis inhalerbart og torakalt støv (21). Det var ingen assosiasjon mellom fall i lungefunksjon og eksponering, noe som tyder på at andre forhold enn den målte støvfraksjonen er av betydning. Det er behov for flere studier, men resultatene kan gi mistanke om at arbeid ved gjødselfabrikken gir økt risiko for kols.

I en studie fra 2010 der man fulgte 2620 arbeidstakere ved norske smelteverk i fem år og benyttet jobbeksponeringsmatriser for karakterisering av eksponering, falt $\mathrm{FEV}_{1} /$ høyde $^{2}$ i takt med økende støvnivå (22). Årlig reduksjon av $\mathrm{FEV}_{1} /$ høyde $^{2}$ for en arbeidstaker $(1,80 \mathrm{~cm}$ høy) var $5,7 \mathrm{ml} /$ år i smelteverk der det produseres silisiummangan, ferromangan og ferrokrom, mens den var 6,4 ml/år for en ikke-røykende arbeidstaker i smelteverk der det produseres ferrosilisium og silisiummetall. $\mathrm{FEV}_{1}$ var lavere for kvinner enn for menn. Forfatterne har $\mathrm{i}$ en oversiktsartikkel oppsummert at det er gode holdepunkter for økt forekomst av kols 
Tabell 2 Studier identifisert giennom oppdaterte litteraturs $\varnothing \mathrm{k}$ om arbeidsrelatert kols. Alle studier er justert for alder og røyking, og alle konfidensintervaller (KI) er $95 \%$. GOLD: Global Initiative for Chronic Obstructive Disease, FVC: forsert vitalkapasitet, FEV sekund, IRR: justert insidensrateratio. LLN: laveste normalnivå, som tilsvarer 5-prosentilen i en frisk, ikke-røykende populasjon, GM: geometrisk median

\begin{tabular}{|c|c|c|c|c|}
\hline $\begin{array}{l}\text { Førsteforfatter, år } \\
\text { (referanse) }\end{array}$ & Eksponering & Design & Populasjon & Utfall \\
\hline Metha, 2012 (12) & $\begin{array}{l}\text { Jobbeksponeringsmatrise } \\
\text { basert på yrkeskoder }\end{array}$ & $\begin{array}{l}\text { Populasjons- } \\
\text { studie; } 10-12 \text { år }\end{array}$ & $N=4267$ (18-62 år) & Kols GOLD Grad II+ \\
\hline Mirabelli, 2012 (13) & $\begin{array}{l}\text { Jobbeksponeringsmatrise } \\
\text { basert på yrkeskoder }\end{array}$ & $\begin{array}{l}\text { Populasjons- } \\
\text { studie; } 3 \text { år }\end{array}$ & $N=8967$ (45-64 år) & $\begin{array}{l}\text { RR - symptomer } \\
\text { sammenliknet } \\
\text { med ueksponerte, } \\
\mathrm{FEV}_{1}<\mathrm{LLN} \\
\mathrm{FEV}_{1} / \mathrm{FV}<<\mathrm{LLN}\end{array}$ \\
\hline
\end{tabular}

$\begin{array}{cl}\text { De Jong, } 2014 \text { (14) } & \begin{array}{l}\text { Jobbeksponeringsmatrise } \\ \text { basert på yrkeskoder }\end{array} \\ \text { Möhner, 2012 (15) } & \begin{array}{l}\text { Gruveindustri } \\ \text { Jobbeksponeringsmatrise } \\ \text { Kvarts: } 1 \mathrm{mg} / \mathrm{m}^{3} \text { over } 220 \\ \text { skift à } 8 \text { timer/år }\end{array} \\ \text { Shi, 2010 (16) } & \begin{array}{l}\text { Tekstilindustri } \\ \text { Endotoksin: } \mathrm{median} \\ 2086-1289 \mathrm{EU} / \mathrm{m}^{3} \text { for } \\ \text { 1981-92, 98 EU/m³ i } 1996\end{array} \\ \text { Webber, 2011 (17) } & \begin{array}{l}\text { Deltakelse i brann- } \\ \text { og redningsarbeid } \\ \text { ved World Trade Center } \\ \text { (dag 0-14) }\end{array}\end{array}$

$\begin{array}{ll}\text { Aldrich, } 2013 \text { (18) } & \begin{array}{l}\text { Generelt brann- } \\ \text { og redningsarbeid }\end{array} \\ \text { Nordby, } 2013(19)^{1} & \begin{array}{l}\text { Sementproduksjon } \\ \text { Jobbeksponeringsmatrise } \\ \text { Torakalt st } ø \text { V: } \\ 0,14-14 \mathrm{mg} / \mathrm{m}^{3}\end{array}\end{array}$

$\begin{array}{lll}\begin{array}{l}\text { Populasjons- } \\ \text { studie; } 25 \text { år }\end{array} & N=2527(30-80 \text { år) } & \begin{array}{l}\text { FEV }_{1} \text {-reduksjon } \\ \text { per år }\end{array} \\ \begin{array}{ll}\text { Kasus-kontroll- } \\ \text { studie; } 8 \text { år }\end{array} & \begin{array}{l}\mathrm{N}=233 \text {, referanse- } \\ \text { gruppe: } 1115\end{array} & \text { KOLS Grad I+/II+ } \\ \text { (f. 1954-56) } & \end{array}$

Kasus-kontrollstudie; 25 år
$\mathrm{N}=447$, referanse- gruppe: 572 (27-47 år ved inklusjon)

Kasus-kontrollstudie; 7-9 år

$N=9715$, referansegruppe: $1228(18-64+)$

$\mathrm{FEV}_{1} / \mathrm{FVC}$ i forhold til legediagnostisert obstruktiv lungesykdom

$\mathrm{FEV}_{1}$-reduksjon/år

Tidligere eksponering endotoksin: $F E V_{1}$ : ansatt < 5 år før baseline: 93 (19-205), ansatt $\geq 5$ år: 30 (43-104), > 10 år: 39 (50-129)

Laveste kvintil av $\mathrm{FEV}_{1} / \mathrm{FVC}$ $0,5 \%$ kols, $9,2 \%$ kronisk bronkitt, 9,4\% rapporterte astma - mot henholdsvis $0,3 \%, 1,1 \%$ og $4,2 \%$ i referansegruppen

Kasus-kontroll- $\quad \mathrm{N}=940$, referanse- $\quad \mathrm{FEV}_{1} / \mathrm{FVC}$-redukstudie; 5 år $\quad$ gruppe : 97 (25-44 år) sjon/år

Kohortstudie; $\quad N=4998$ (17-54 år) 4-5 år

Reduksjon $\mathrm{FEV}_{1}$ $\mathrm{m}^{2}$ per år og per $\mathrm{mg} / \mathrm{m}^{3}$

Brannmenn: FEV 1 /FVC: 45 (42-48) ml/år. Referansegruppen: 45 (35-54)

Alle eksponerte: $F E V_{1} / \mathrm{m}^{2}: 2,9$ $(2,5-3,2) \mathrm{ml} / \mathrm{m}^{2} \cdot\left(\mathrm{a} r \cdot \mathrm{mg} / \mathrm{m}^{3}\right)$ Laveste eksponeringskategori: $\left(0,6-1,6 \mathrm{mg} / \mathrm{m}^{3}\right)$ : $9,7(7,6-12)$ Høyeste $\left(5,4-14 \mathrm{mg} / \mathrm{m}^{3}\right)$ : $19(15-22)$

\section{Tungu, 2014 (20) Sementproduksjon Totalstøv før og etter reduksjon: 10,6 og $5,8 \mathrm{mg} / \mathrm{m}^{3}$}

Kasus-kontrollstudie; 2 år
$N=120$, referanse-
gruppe: 107 (24-49 år)

\section{$\mathrm{FEV}_{1} / \mathrm{FVC}<0,7$}

Før støvreduksjon: $F E V_{1} / F V C$ $<0,7: 22,6 \%$, referansegruppen: $5,9 \%$

Etter støvreduksjon: $1,9 \%$, referansegruppen: $4,3 \%$

FEV $_{1:} 18(27-10) \mathrm{ml} / \mathrm{a} r$

Hovland, 2013 (21)1 Nitratgjødselproduksjon Inhalerbar og torakal fraksjon: 1,1 og $0,21 \mathrm{mg} / \mathrm{m}^{3}$

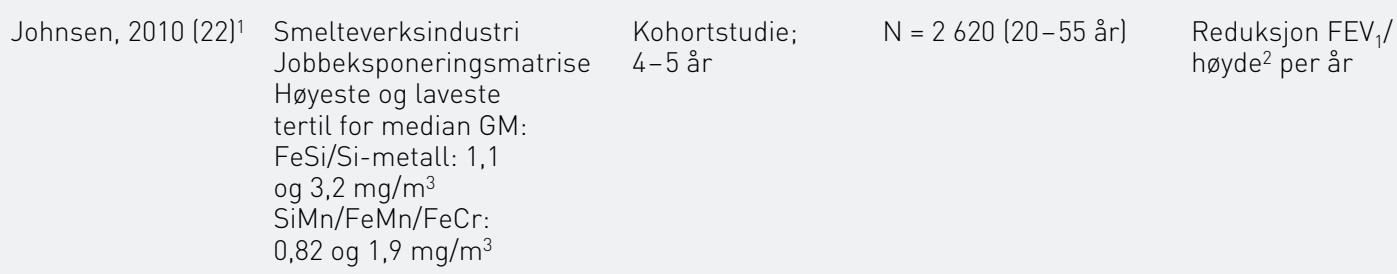

Kohortstudie; 4-5 år

\section{$N=2620(20-55$ år)}

$$
N=2620(20-55 \text { år })
$$

Reduksjon $\mathrm{FEV}_{1} /$ høyde ${ }^{2}$ per år

Kohortstudie; 3 år N N 383 (38-58 år)
FeSi/Si-metall: $\mathrm{FEV}_{1} / \mathrm{m}^{2}$ : $0,42(0,95-0,11)\left(\mathrm{ml} / \mathrm{m}^{2}\right)$ $\left(\mathrm{mg} / \mathrm{m}^{3}\right) \cdot \mathrm{a} r$ $\mathrm{SiMn} / \mathrm{FeMn} / \mathrm{FeCr}$ : $1,1(2,1-0,1)$

\footnotetext{
1 Studier supplert av forfatterne - de var ikke indeksert med de benyttede MeSH-søketermer for obstruktiv lungesykdom
} 
også hos ikke-røykere i smelteverksindustrien (25).

\section{Diagnostiske vurderinger}

Det er vist at de som har vært eksponert for partikler og gass, hadde mer oppspytt og dyspné enn de øvrige kolspasientene (26). I en nyere studie fant man at pasienter med arbeidsrelatert kols hyppigere rapporterte om atopi, piping $\mathrm{i}$ brystet $\mathrm{og}$ arbeidsrelatert uførhet enn de øvrige kolsrammede (27). Vi anbefaler bruk av korte, validerte spørreskjemaer og årlig spirometri for screening for kols for arbeidstakere som blir eksponert for partikler og gass. God opplæring av dem som utfører spirometri bør gis for å sikre pålitelige resultater.

Fordi en del arbeidstakere ikke møter til screeningundersøkelser, oppfordres leger til å informere om risikoer og vernetiltak på arbeidsplasser der det er eksponering for partikler og gass. Det vil kunne bidra til at flere møter og at færre frykter konsekvensene av eventuelle funn.

Spirometriovervåkingsprogrammer kan vurderes for å identifisere dem som er i ferd med å utvikle kols (28). Nedsatt lungefunksjon, men også endringer over tid for dem som har verdier innenfor normalområdene, bør føre til videre utredning og tiltak i arbeidsmiljøet.

Ved familiær opphopning eller tidlig debut av kols anbefales måling av alfa-1antitrypsin i serum. HRCT-undersøkelse (high resolution computed tomography) og supplerende respirasjonsfysiologiske undersøkelser (karbonmonoksiddiffusjonskapasitetsundersøkelse (DLCO), TLC og RV) anbefales for påvisning og vurdering av emfysem. Det bør være lav terskel for henvisning til arbeidsmedisinsk og/eller lungemedisinsk avdeling, fordi utredningen er tidkrevende og regelverk for godkjenning av yrkesskade komplisert.

\section{Prognose, tiltak og forebygging}

Primærforebygging på arbeidsplassen kan oppnås ved eksponeringsreduksjon, gjennom både tekniske og organisatoriske tiltak. Det er videre viktig å sikre bruk av adekvat verneutstyr når andre tiltak ikke er mulig. Enhver lege som mistenker arbeidsrelatert sykdom, har plikt til å sende melding til Arbeidstilsynet (skjema 154b). Meldingen retter oppmerksomheten mot nye agenser og nye arbeidsmetoder som innebærer økt risiko for kols. Arbeidstilsynet kan følge opp med arbeidsplassbesøk og pålegg om tiltak, slik at nye tilfeller kan forhindres. Det er fortsatt viktig å stimulere til røykeslutt.

Hva så når diagnosen arbeidsrelatert kols er stilt? Hvilke råd skal gis? Kan pasienten fortsette $\mathrm{i}$ arbeid? Personer med arbeidsrelatert kols kan ha nedsatt arbeidsevne og lavere livskvalitet enn øvrige kolspasienter $(26,29)$. Man skal imidlertid være forsiktig med å anbefale pasienten å slutte i jobben, fordi erfaring viser at mange sliter med å komme tilbake i arbeid. Det bør tilstrebes samarbeid med bedriftshelsetjenesten for tilrettelegging på arbeidsplassen og med arbeids- og lungemedisinske avdelinger som innehar spesialkompetanse om substanser og arbeidsoppgaver som bør unngås.

Karakteristika ved enkeltindividet, som røykevaner, alder, og kjønn kan ha betydning for risikoen ved arbeidsrelatert kols. En studie fra 2008 viste at kvinnelige (men ikke mannlige) ansatte som var eksponert for trestøv, fikk et støvrelatert fall i $\mathrm{FEV}_{1}$ på 25 $\mathrm{ml} / \mathrm{a}$ (30). Til sammenlikning gir røyking gjennomsnittlig et fall på $10 \mathrm{ml} / \mathrm{år}(31)$. Sunyer og medarbeidere (32) har tidligere vist større nedgang i $\mathrm{FEV}_{1}$ hos kvinner som er eksponert for høye nivåer av både biologisk støv og mineralstøv. En av de foreslåtte forklaringene var at kvinners størrelse på luftveiene er mindre enn hos menn.

Fordi det vil være sårbare individer i alle grupper, bør imidlertid målet være å senke eksponeringsnivået for alle arbeidstakere, uavhengig av individuelle sårbarhetsfaktorer

\section{Konklusjon}

Nyere studier viser økt risiko for kols ved eksponering for kvarts ved dagens eksponeringsnivåer og for ansatte i sementproduksjon og ved smelteverk, mens sammenhengen er mer usikker for brannmenn og ansatte i nitratgjødselproduksjon. For øvrig bekreftes funn fra tidligere oversiktsstudier, som konkluderer med at det er tilstrekkelig kunnskap for å kunne si at en rekke organiske og uorganiske eksponeringer $\mathrm{i}$ arbeid kan gi kols. Alle pasienter der det er mistanke om arbeidsrelatert kols, bør henvises til arbeidsmedisinsk vurdering.

\section{Anne Kristin Møller Fell (f. 1966)}

er ph.d., overlege, spesialist i arbeidsmedisin og postdoktorkandidat. Hun har erfaring fra forsk-

ning og utredning av pasienter med arbeidsrela terte lungesykdommer og er medlem av kurs-

komiteen for arbeidsrelaterte lungesykdommer i Nordic Institute for Advanced Training in Occupational Health (NIVA).

Forfatter har fylt ut ICMJE-skjemaet og oppgir ingen interessekonflikter.

\section{Tor Olav Brøvig Aasen (f. 1946)}

er spesialist i lungesykdommer og $i$ indremedisin, med spesiell kompetanse innen arbeidsrelaterte lungesykdommer. Han er tidligere avdelingsoverlege og avdelingsdirektør, nå spesialrådgiver/pensjonist.

Forfatter har fylt ut ICMJE-skjemaet og oppgir ingen interessekonflikter.

\section{Johny Kongerud (f. 1949)}

er avdelingsleder, professor II og spesialist $\mathrm{i}$ indremedisin og i lungesykdommer. Han har mangeårig forskningserfaring og klinisk erfaring innen feltet yrkesbetingede lungesykdommer.

Forfatter har fylt ut ICMJE-skjemaet og oppgir ingen interessekonflikter.

\section{Litteratur}

1. Global Strategy for the Diagnosis, Managemen and Prevention of COPD, Global Initiative for Chronic Obstructive Lung Disease. 2013. www.goldcopd.org/Guidelines/guidelinesresources.html (21.10.2014)

2. Balmes J, Becklake M, Blanc $P$ et al. American Thoracic Society Statement: Occupational contribution to the burden of airway disease. Am J Respir Crit Care Med 2003; 167: 787-97.

3. Salvi SS, Barnes PJ. Chronic obstructive pulmonary disease in non-smokers. Lancet 2009; 374 : 733-43.

4. Halvorsen T, Martinussen PE. The geography of chronic obstructive pulmonary disease: a popula tion-based study of Norway. Soc Sci Med 2014; 111: $25-34$

5. Lamprecht B, McBurnie MA, Vollmer WM et al. COPD in never smokers: results from the population-based burden of obstructive lung disease study. Chest 2011; 139: 752-63.

6. Naidoo RN. Occupational exposures and chronic obstructive pulmonary disease: incontrovertible evidence for causality? Am J Respir Crit Care Med 2012; 185: 1252-4.

7. Blanc PD. Occupation and COPD: a brief review. J Asthma 2012; 49: 2-4.

8. Ulvestad B, Bakke B, Eduard W et al. Cumulative exposure to dust causes accelerated decline in lung function in tunnel workers. Occup Environ Med 2001: 58: 663-9

9. Leira HL. Kols - ikke bare hos røykere. Tidsskr Nor Legeforen 2011; 131: 1756-7.

10. Omland O, Würtz ET, Aasen TB et al. Occupational chronic obstructive pulmonary disease: a systematic literature review. Scand J Work Environ Health 2014: 40: 19-35.

11. Haz-Map. Information on hazardous chemicals and occupational diseases. www.hazmap. $\mathrm{nlm}$. nih.gov (21.10.2014)

12. Mehta AJ, Miedinger D, Keidel D et al. Occupational exposure to dusts, gases, and fumes and incidence of chronic obstructive pulmonary disease in the Swiss Cohort Study on Air Pollution and Lung and Heart Diseases in Adults. Am J Respir Crit Care Med 2012: 185: 1292-300.

13. Mirabelli MC, London SJ, Charles LE et al. Occupation and three-year incidence of respiratory symptoms and lung function decline: the ARIC Study. Respir Res 2012; 13: 24.

14. de Jong $\mathrm{K}$, Boezen HM, Kromhout $\mathrm{H}$ et al. Pesticides and other occupational exposures are associated with airway obstruction: the LifeLines cohort study. Occup Environ Med 2014; 71: 88-96.

15. Möhner M, Kersten N, Gellissen J. Chronic obstructive pulmonary disease and longitudinal changes in pulmonary function due to occupational exposure to respirable quartz. Occup Environ Med 2013; 70: 9-14

16. Shi J, Mehta AJ, Hang JQ et al. Chronic lung func tion decline in cotton textile workers: roles of historical and recent exposures to endotoxin. Environ Health Perspect 2010; 118: 1620-4

17. Webber MP, Glaser MS, Weakley J et al. Physiciandiagnosed respiratory conditions and mental health symptoms 7-9 years following the World Trade Center disaster. Am J Ind Med 2011; 54: $661-71$. 
18. Aldrich TK, Ye F, Webber MP et al. Longitudinal pulmonary function in newly hired, non-World Trade Center-exposed fire department City of New York firefighters: the first 5 years.

Chest 2013; 143: 791-7. http://www.ncbi.nlm.nih. gov/pubmed/23188136

19. Nordby KC. Prospective monitoring of exposure and lung function among cement production workers - an international study. Occup Environ Med 2013; 70 (suppl 1): A141.

20. Tungu AM, Bråtveit M, Mamuya SH et al. The impact of reduced dust exposure on respiratory health among cement workers: an ecological study. J Occup Environ Med 2014; 56: 101 -10.

21. Hovland KH, Skogstad M, Bakke B et al. Longitudinal lung function decline among workers in a nitrate fertilizer production plant. Int J Occup Environ Health 2013; 19: 119-26.

22. Johnsen HL, Hetland SM, Benth JS et al. Dust exposure assessed by a job exposure matrix is associated with increased annual decline in FEV1. a 5-year prospective study of employees in Norwegian smelters. Am J Respir Crit Care Med 2010; 181: $1234-40$

23. Delclos GL, Gimeno D, Arif AA et al. Occupational exposures and asthma in health-care workers: comparison of self-reports with a workplace-specific job exposure matrix. Am J Epidemiol 2009; 169: $581-7$

24. Bergdahl IA, Torén K, Eriksson $K$ et al. Increased mortality in COPD among construction workers exposed to inorganic dust. Eur Respir J 2004; 23 402-6.

25. Søyseth V, Johnsen HL, Kongerud J. Respiratory hazards of metal smelting. Curr Opin Pulm Med 2013; 19: 158-62

26. Rodríguez E, Ferrer J, Martí S et al. Impact of occupational exposure on severity of COPD. Chest 2008: 134: 1237-43.

27. Caillaud D, Lemoigne F, Carré $P$ et al. Association between occupational exposure and the clinical characteristics of COPD. BMC Public Health 2012; 12: $302-9$

28. Hznido E, Yan T. Hakobyan A et al. Longitudinal data analysis software for analysis of spirometry data in workplace prevention or COPD Treatment. Open Med Inform J 2004: 94-102.

29. Blanc PD, Eisner MD, Trupin L et al. The association between occupational factors and adverse health outcomes in chronic obstructive pulmonary disease. Occup Environ Med 2004; 61: 661-7.

30. Jacobsen G, Schlünssen V, Schaumburg I et al. Longitudinal lung function decline and wood dust exposure in the furniture industry. Eur Respir $\mathrm{J}$ 2008; 31: 334-42.

31. Lee PN, Fry JS. Systematic review of the evidence relating FEV1 decline to giving up smoking. BMC Med 2010: 8: 84

32. Sunyer J, Zock JP, Kromhout $H$ et al. Lung function decline, chronic bronchitis, and occupational exposures in young adults. Am J Respir Crit Care Med 2005; 172: 1139-45.

Mottatt 28.2. 2014, første revisjon innsendt 17.6. 2014, godkjent 21.10. 2014. Redaktør: Trine B. Haugen.

\section{Skal du sende inn}

\section{et manuskript til Tidsskriftet?}

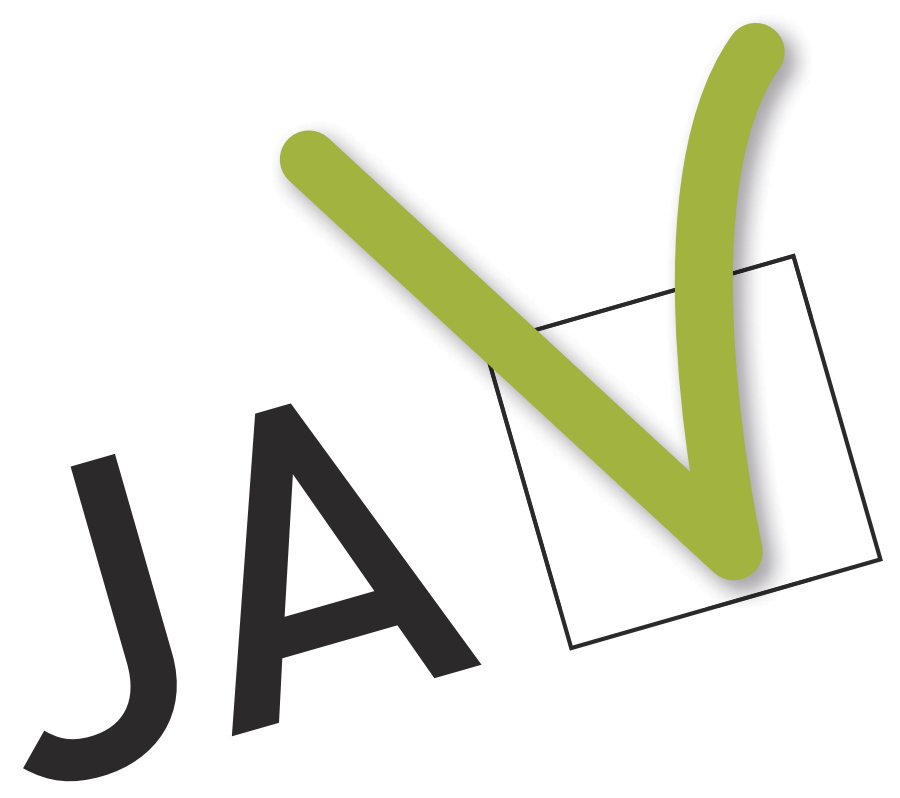

\section{Ved omtale av pasienter eller ved bruk av bilder av pasienter skal Tidsskriftets samtykkeskjema benyttes.}

Skjemaet finner du i Forfatterveiledningen under etikk og jus.

Tidsskrift for

www.tidsskriftet.no 